\title{
Use of Morphometric Analyses to Assess the Efficacy of the Technique of Resin Composite Bonded to Cervical Dentin with Additional Mechanical Retentions
}

\author{
Uso de Análisis Morfométrico para Evaluar la Eficacia de la Técnica de Resina \\ Compuesta Unida a Dentina Cervical con Retenciones Mecánicas Adicionales
}

\author{
Gisaku Kuramochi*; Eduardo Borie ${ }^{* *} \&$ Mariano del Sol ${ }^{* * * * * * *}$
}

KURAMOCHI, G.; BORIE, E. \& DEL SOL, M. Use of morphometric analyses to assess the efficacy of the technique of resin composite bonded to cervical dentin with additional mechanical retentions. Int. J. Morphol., 34(2):597-603, 2016.

SUMMARY: The structural changes and morphological derivatives of progressive dentin hypermineralization determine the bonding to its surface. A planimetric study and fracture volume estimate were conducted to assess the efficacy of resin composite bonded to hypermineralized cervical dentin with and without retentions by applying a shear test. Thirty-four premolars from adult patients were used to obtain a flat cervical dentin surface. The specimens were distributed randomly into two groups: 1) experimental, where hemispherical retentions were carved into the cervical dentin, and 2) control, where the flat dentin was maintained. Using a jig, a resin column was built into the dentin surface fitted with bonding in specimens from both groups, which were then subjected to the shear test. The morphological analysis was performed with a microscope while the percentage of remnant surface from each component of the adhesive bond was calculated planimetrically. The volume of lost tissue was determined using Scherle's method. In the planimetric study, the average remnant resin on the surface was significantly higher in the experimental group and there was less intact dentin in the control group. The volumetric assessment also showed a much higher loss of dentin substrate than the experimental group. Consequently, the complementary use of morphometric and volumetric techniques enables the evaluation of the efficacy of a technique, demonstrating that the inclusion of mechanical retentions in hypermineralized cervical dentin improves the bonding properties.

KEY WORDS: Morphometry; Planimetry; Volumetry; Bonding; Dentin.

\section{INTRODUCTION}

Despite technological advances in the development of new adhesive systems in dentistry and knowledge of bonding on dental tissues, the confluence of a series of factors is currently making proper bonding to dentin a particularly critical issue (van Dijken et al., 2007; Peumans et al., 2012).

In addition to the bonding technique used (van Meerbeek et al., 2005) and the physicochemical properties of the bonds (Spencer et al., 2005), structural and morphological changes resulting from progressive hypermineralization suffered over time (Kowng et al., 2002; Karan et al., 2009) determine the bonding of resin restorations (Ritter et al., 2008).

Unfortunately, the presence of sclerotic dentin is related to a group of various lesions of mixed etiology known as non-carious cervical lesions (NCCL) (Grippo et al., 2004), the incidence of which is rising due to higher life expectancy and more dental pieces in the oral cavity (Borcic et al., 2004). Moreover, an increase in the size and number of these lesions is observed with age (Bernhard et al., 2006), a situation that has increased clinical attention.

Advances in the formulation of new adhesive systems and techniques are generally assessed using mechanical tests which, despite their limitations (Heintze, 2013), have contributed significantly to the development of adhesive dentistry (Scherrer et al., 2010)

In spite of the outstanding issues, the morphological and stereological techniques are underused. For example, it is possible to find in the literature high indices of variation

* Department of Restorative Dentistry, School of Dentistry, Universidad Finis Terrae, Santiago, Chile

* CICO Research Centre, Dental School, Universidad de La Frontera, Temuco, Chile.

**** Department of Basic Sciences, CEMyQ, School of Medicine, Universidad de La Frontera, Temuco, Chile.

${ }^{* * * * *}$ Center for Research in Biomedical Sciences, Universidad Autónoma de Chile, Temuco, Chile. 
between the different morphological studies of fractures (Korkmaz et al., 2010). This occurs basically due to the lack of consensus in the classification of fractures, measurements made with different instruments (Korkmaz et al.) and the inclusion in the analyses of non-representative specimens of the phenomenon being studied (Ghassemieh, 2008). In addition, it is important to emphasize that most induced fracture analyses via mechanical testing are subjective in nature, thereby diminishing the relevance of their conclusions (Scherrer et al.). By contrast, the use of planimetry (Tschanz et al., 2011) and volumetry (Scherle, 1970) allow us to approach the analysis quantitatively, and therefore the techniques and adhesive properties of the different adhesive systems can be compared by objective and complementary means.

Besides the improvements introduced in the adhesives and the attempts by some authors to increase the bonding values of the resins by modifying the surface of the sclerotic dentin (Luque-Martinez et al., 2013). Brackett et al. (2005) suggest the inclusion of additional mechanical retentions in class $\mathrm{V}$ restorations located in areas of highly concentrated stress and surfaces with poor adhesion. Nevertheless, techniques that include these types of retentions or cavity designs that explore new forms of retention have not really been assessed.

In this context, the aim of this study was to use a planimetric study and fracture volume estimate to assess the efficacy of the technique of resin composite bonded to hypermineralized cervical dentin with and without retentions by applying a shear test.

\section{MATERIAL AND METHOD}

This study was approved by the Ethics Committee of the Universidad de La Frontera, Temuco, Chile (Protocol $\left.n^{\circ} 003 / 2014\right)$.
Thirty-four premolars free of caries with therapeutic indication for extraction due to advanced periodontal disease from patients aged between 50 and 60 years were selected to obtain an even number of hypermineralized cervical dentin surfaces. Once extracted, each tooth was debrided with a curette (Gracey Curette N5, Hu-Friedy Mfg. Co., Chicago, IL, USA), cleaned with hard prophy brushes, disinfected in $5 \%$ sodium hypochlorite in order to finally wash them in distilled water and store them for a month in an isotonic saline solution with $1 \%$ formalin.

To prepare the study surface and bond a resin cylinder on to it, the specimens required individual silicone molds (FlexiFormÒ, Struers, Ballerup, Denmark) where the teeth were positioned with one of their proximal faces aimed at the surface and embedded in self-curing epoxy resin (LR WhiteTM Resin system, London Resin Company Ltd, Berkshire, UK) (Fig. 1A). Once polymerization was complete, the specimens were removed (Fig. 1B) and their surface worn and polished sequentially with $\mathrm{SiCa}$ discs in a horizontal grinder (LaboPol-5, Struers, Ballerup. Denmark) under abundant water until a flat cervical dentin surface was obtained (Fig. 1C). This process was monitored with a stereo microscope at 16X magnification (Leica MS5, Leica Microsystems GmbH, Wetzlar, Germany).

Next the specimens were randomly assigned to one of the groups ( $n=17)$ : 1) Experimental group (EG), in which hemispheric mechanical retentions were carved onto the cervical dentin surface, and 2) Control group (CG) with no additional mechanical retentions (Fig. 2A).

The shear test was done according to the recommendations suggested by ISO standards (ISO 29022, 2013). A jig (Ultradent, South Jordan, UT, USA) was used, designed with a bonding template with a $4 \times 4.72 \mathrm{~mm}$ hole to circumscribe the carving of four hemispheric cavities with a high-speed carbide bur (C1 FG 010, Jota AG, Rüthi, Switzerland) under abundant water in the area of interest in specimens from the EG (Fig. 2B) and the construction of a

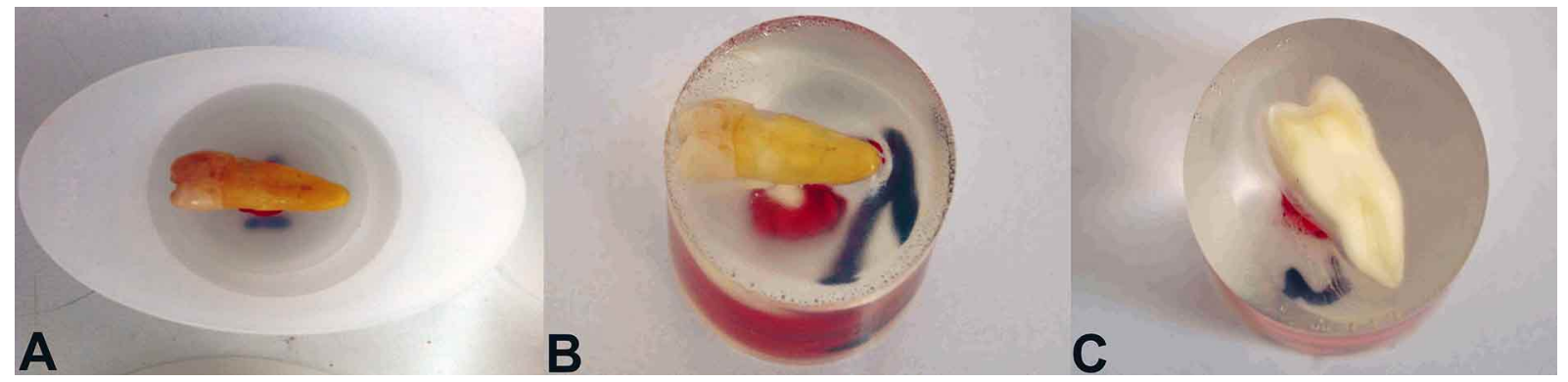

Fig. 1. Preparation of the specimens. A) tooth positioned within the silicon mold and embedded in epoxy resin. B) Polymerized resin cylinder released from mold and C) Upper view of an abraded and polished dentin surface. 
resin composite cylinder (Filtek Z100 shade A2, 3M ESPE, St. Paul, MN, USA) perpendicular to the surface prepared in specimens from both groups (Fig. 2C-E). The self-etch adhesive system Prompt-1 pop (3M ESPE, Seefeld, Germany) was applied by closely following the manufacturer's instructions (Fig. 2C).

The adhesive and the resin composite were photopolymerized using a $1200 \mathrm{~mW} / \mathrm{cm} 2$ LED unit (3M ESPE EliparTM, 3M Deutschland GmbH, Neuss, Germany) (Fig. D-E), the emission of which was periodically monitored with a radiometer (Demetron, Kerr, Orange, CA, USA).

Shear Test. Prior to application of the shear test the specimens were incubated for $24 \mathrm{~h}$ at $37^{\circ} \mathrm{C}$ (Fig. 2F). A universal testing machine (Z100, Zwick Roell, Ulm, Denmark) was used, which contained a blade with a notched edge (Ultradent, South Jordan, UT, USA) designed to coincide with the cylinder diameter (Fig. 2G). The shear load was applied at a crosshead speed of $0.5 \mathrm{~mm} / \mathrm{min}$ in an occlusogingival direction $1 \mathrm{~mm}$ from the interface of the dentin-resin composite bond (Placido et al., 2007). All the shear resistance values were recorded and expressed in megapascals (MPa).

Planimetric study. After performing the shear strength tests, the fractured specimens were examined under a stereomicroscope (16x) (Leica MS5, Leica Microsystems GmbH, Wetzlar, Germany); digital images of the study area were captured, and a planimetric study was conducted to determine the area $\left(\mu \mathrm{m}^{2}\right)$ of the i) cohesive dentin fracture, ii) adhesive remnant, iii) cohesive composite fracture and iv) intact dentin (Fig. 3A).

By analyzing digital images of the cross-sections, the fracture surfaces were distinguished, mounting them on a planimetric point-count system (Test System M36) of calibrated distance and area. All evaluations considered the compression factor and were performed as described by Tschanz et al. with the multipurpose M36 test and the STEPanizer ${ }^{\circledR}$ software (Stepanizer software, Bern, Switzerland) (Fig. 3B).

Volumetric study. To determine the volume of dentin tissue lost after application of the shear test, the surface of the fractured area in each specimen was filled by adding silicone (Panasil Putty Soft, Kettenbach $\mathrm{GmbH} \& \mathrm{Co}$. KG, Eschenburg, Germany). One hour after curing, the silicone was removed and weighed individually on an A \& D Orion HR 120 analytical balance $(0.1 \mathrm{mg}$ to $120 \mathrm{~g}$ ) (A \& D Engineering, CA, USA), determining the volume involved by means of Scherle's method (Scherle).

Statistical analysis. For the planimetry, the average and standard deviation of the percentage of the area of each element of the adhesive bond were calculated. The normal distribution of the data and equal variances were analyzed by the Shapiro-Wilk test and Levene's test, respectively.
Fig. 2. Schematic design of the experiment. A) Random assignment of groups; B) Retention carvings; C) Adhesive application; D) Light-curing; E) Composite resin cylinder conformation using a template; F) Storage incubator and G) Shear bond test performed in an universal testing machine. 


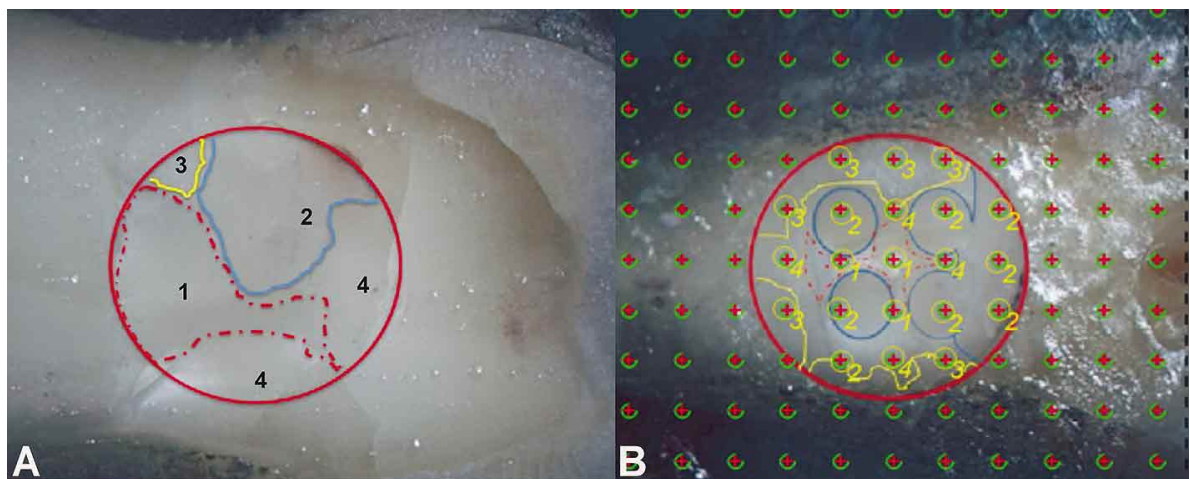

Fig. 3. A) Description of the surfaces: 1- cohesive dentin fracture; 2- cohesive resin fractures; 3adhesive remnants; and 4- the remnant intact dentin. B) STEPanizer interface

Because the assumptions were met, the means were compared using student's t-test, with a significance level of $\mathrm{p}<0.05$.

The volumetric analysis calculated the median and standard deviation. The two techniques were compared using the Mann-Whitney test with a significance level of $\mathrm{p}<0.05$.

In both studies the statistical analysis was performed using the Statistical Package for Social Sciences (SPSS) v. 16.0 software (SPSS Inc., Chicago, IL, USA).

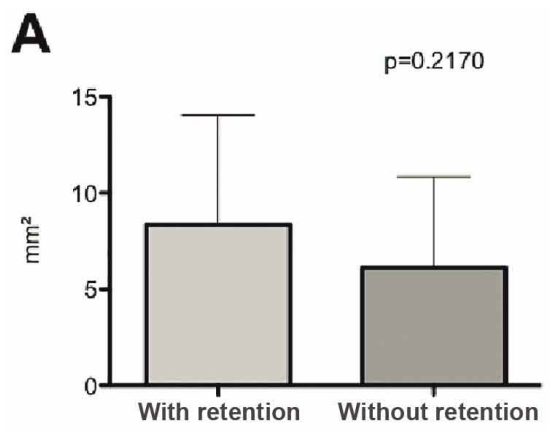

C

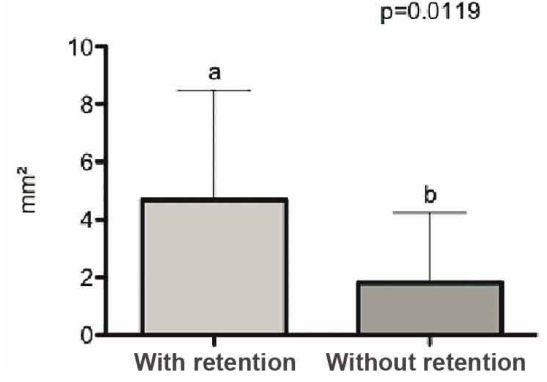

\section{RESULTS}

For the technique with additional mechanical retentions, the predominant fracture pattern was cohesive and occurred in the dentin and resin composite, whereas in the CG a predominance of remnant intact dentin was observed without cohesive fractures (Table I).

In terms of the percentage of surface area (PSA) observable of each component of the bond after shearing, the

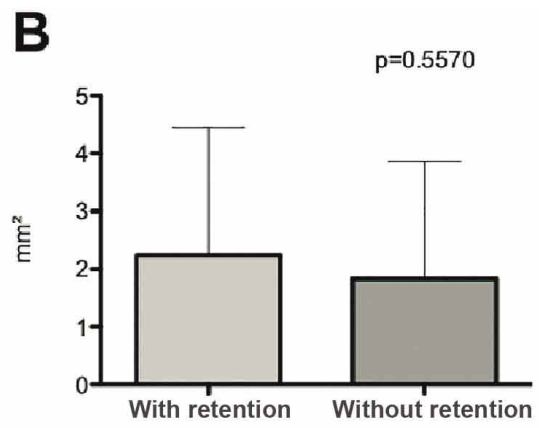

D

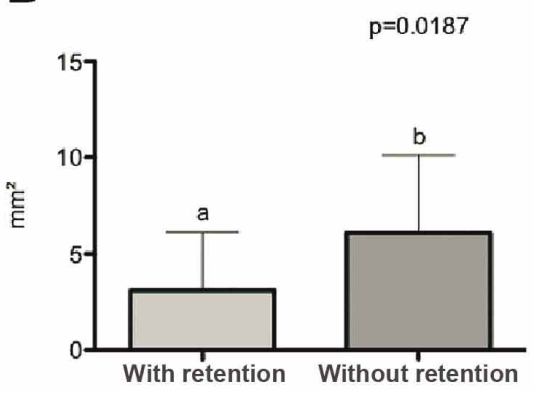

Fig. 4. Data distribution (t-test) between the two groups for each layer. A) Fractured dentin; B) Remnant adhesive; C) Remnant composite and D) Remnant intact dentin. 
Table I. Surface of bond interface components present in each group after the shear test.

\begin{tabular}{|c|c|c|c|c|c|c|c|c|}
\hline & \multicolumn{2}{|c|}{$\begin{array}{c}\text { Cohesive dentine } \\
\text { fracture }\end{array}$} & \multicolumn{2}{|c|}{$\begin{array}{l}\text { Remnant } \\
\text { Adhesive }\end{array}$} & \multicolumn{2}{|c|}{$\begin{array}{c}\text { Remnant } \\
\text { Composite }\end{array}$} & \multicolumn{2}{|c|}{$\begin{array}{c}\text { Remnant } \\
\text { Intact Dentine }\end{array}$} \\
\hline & $\begin{array}{c}\text { Mean } \pm \text { SD } \\
\mathbf{m m}^{2}\end{array}$ & $\%$ & $\begin{array}{c}\text { Mean } \pm \text { SD } \\
\mathbf{m m}^{2}\end{array}$ & $\%$ & $\begin{array}{c}\text { Mean } \pm \text { SD } \\
\mathbf{m m}^{2}\end{array}$ & $\%$ & $\begin{array}{c}\text { Mean } \pm \text { SD } \\
\mathbf{m m}^{2}\end{array}$ & $\%$ \\
\hline Experimental Group & $8.35 \pm 5.7$ & 45.4 & $2.24 \pm 2.2$ & 12.2 & $4.68 \pm 3.77$ & 25.5 & $3.10 \pm 3.01$ & 16.9 \\
\hline Control Group & $6.12 \pm 4.73$ & 38.6 & $1.83 \pm 2.03$ & 1.83 & $1.81 \pm 2.43$ & 11.4 & $6.08 \pm 4.06$ & 38.4 \\
\hline
\end{tabular}

planimetry results reveal that the EG had a PSA of remnant resin composite greater than the $\mathrm{CG}$. However, in the $\mathrm{CG}$ the greater PSA observed corresponded to intact dentin (Table I).

The results delivered by student's t-test showed significant differences $(\mathrm{p}=0.019)$ between the means of remnant composite resin in the control group $(1.81 \pm 2.43$ $\mathrm{mm}^{2}$ ) and the experimental group $\left(4.68 \pm 3.77 \mathrm{~mm}^{2}\right)$. Likewise, a comparison of the means of the surface of remnant intact dentin revealed a greater significant difference $(\mathrm{p}=0.0187)$ in the EG (Fig. 4).

Volumetric Analysis. The application of the Mann-Whitney $\mathrm{U}$ test showed the existence of significant differences between the two techniques $(\mathrm{p}=0.008)$, with a greater loss of substrate volume being observed in the EG (Fig. 5).

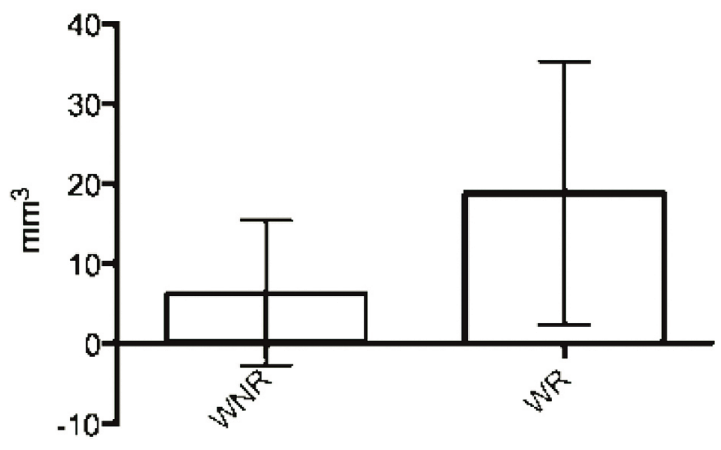

Fig. 5. Distribution of the variable volume of lost dentin with each technique.

\section{DISCUSSION}

Obtaining a reliable and lasting dentin-adhesive bond to dental tissues has stimulated the development of a series of technological advances in relation to the chemical composition of resin composites and different adhesive systems. These improvements have sought to increase the bonding capacity (Ozer \& Blatz, 2013; Tjaderhane et al., 2013) while reducing working time and the sensitivity of the technique (van Meerbek et al.).
Without question these efforts are essential given the protective barrier role the bond interface plays in defending against the lytic attack suffered by resin restorations in the oral cavity (Pashley et al., 2004) and therefore in their survival (Cardoso et al., 2011).

In particular, bonding to dentin can be especially complex depending on its location and on the structural and morphological changes determined by the continuous increase of its degree of hypermineralization (Kowng et al.; Karan et al.). This process causes a decrease in the modulus of elasticity of the dentin, altering its mechanical properties (Martín et al., 2010), and therefore affecting the bonding of the resin restorations, the mechanical behavior of which must adapt to the progressive sclerosis and at the same time to the location of the lesions in the tooth (Guimaraes et al., 2014). For this purpose, adhesive systems are constantly being developed with formulations that vary in terms of the properties of their components as well as the proportion in which these are present (Drummond, 2008; Zakir et al., 2013).

Delving more deeply into the data from the shear test, the results obtained in this study show that with respect to the percentage of the remnant area of intact dentin, there is a significantly smaller difference between the two techniques, where the average was lower in the EG (17 $\%)$ that in the $\mathrm{CG}(30 \%)$. The difference in the percentage of area of remnant resin was also significant, with a greater presence being observed in the EG. In both cases the resulting differences may be due to the presence of retentions in the EG, which on the one hand implies an increase in the contact surface between the interface components, and on the other the inclusion of resin inside them generates a change of material that brings about a redistribution of forces when the bond is loaded. This way, when the fault in the resin composite-dentin bond is induced with the application of the shear test, the additional contact surface provided by the retentions involves more dentin, causing a cohesive fracture of this substrate, a phenomenon facilitated by the depth of the preparations in the dentin (Ivancik \& Arola, 2013). At the same time, these retentions tend to prevent the resin from being dislodged, which causes a cohesive fracture. 
However, the comparison of the data given by planimetry with respect to the percentage of the area of fractured dentin did not detect statistically significant differences between the two techniques. The volumetric analysis did reveal a significant loss of dentin tissue in the EG, which demonstrates the complementary nature of the two techniques when we endeavor to perform a quantitative and $3 \mathrm{D}$ analysis of the remnant surface after the dentin-resin bonding fault induced by the test.

Recent survival studies have suggested that obtaining high values of adhesive force is not necessarily defining in terms of the clinical durability of the restorations (van Dijken et al.; Peumans et al.). This confirms the importance of including morphometric and volumetric approaches for the validation of a complementary technique or assessment in an analysis of bonding force. Certainly both types of analysis provide relevant objective information as to the mechanical behavior of the adhesive and the substrates (Scherrer et al.) involved in the resin-dentin bond of the surface fractured after application of the mechanical test. Nevertheless, their correlation with the clinical behavior of restorations must be established individually for such parameters as microfiltration, bond strength and marginal fit (Heintze), and by association to those studies that evaluate the behavior of the resin-dentin bond interface in terms of resistance to shear forces and traction (Braga et al., 2010; Ivancik \& Arola).

Given the complexity of the interface, various methodologies must continue to be developed and validated by means of laboratory and clinical studies to advance the formulation of new, more predictable adhesive systems and in lines of research that involve the rational use of mechanical retentions or minimally invasive cavity preparations.

\section{CONCLUSION}

The complementary use of morphometric and volumetric techniques enables the evaluation of the efficacy of a technique, demonstrating that the inclusion of mechanical retentions in hypermineralized cervical dentin improves the bonding properties.

KURAMOCHI, G.; BORIE, E. \& DEL SOL, M. Uso de análisis morfométrico para evaluar la eficacia de la técnica de resina compuesta unida a dentina cervical con retenciones mecánicas adicionales. Int. J. Morphol., 34(2):597-603, 2016.

RESUMEN: Los cambios estructurales y morfológicos derivados de la hipermineralización dentinaria progresiva determina la adhesión a su superficie. Fue realizado un estudio planimétrico y el volumen de fractura estimado para evaluar la eficacia de resina compuesta adherida a dentina cervical hipermineralizada con y sin retenciones a través de la prueba de cizalla. Treinta y cuatro premolares obtenidos de pacientes adultos fueron utilizados para obtener una superficie dentinaria cervical plana. Las muestras fueron distribuidas aleatoriamente en dos grupos: 1) experimental, donde se realizaron retenciones hemiesféricas a la dentina cervical, y 2) control, donde la dentina plana fue mantenida. Usando un dispositivo, una columna de resina fue construida en la superficie dentinaria y adaptada con adhesivos en las muestras de ambos grupos, las cuales fueron sometidas al test de cizalla. El análisis morfológico fue realizado con un microscopio mientras que el porcentaje de superficie remanente para cada componente del adhesivo fue calculado planimetricamente. El volumen del tejido perdido fue determinado utilizado el método de Scherle. En el estudio planimétrico, el promedio de resina remanente en la superficie fue significativamente mayor en el grupo experimental y con menos dentina intacta en el grupo control. El análisis volumétrico mostró una mayor perdida de sustrato dentinario en el grupo control. De esta manera, el uso de técnicas morfométricas y volumétricas permite la evaluación de la eficacia de una técnica, demostrando que la inclusión de retenciones mecánicas en la dentina hipermineralizada cervical mejora las propiedades de adhesión.

PALABRAS CLAVE: Morfometría; Planimetría; Volumetría; Adhesión; Dentina.

\section{REFERENCES}

Bernhardt, O.; Gesch, D.; Schwahn, C.; Mack, F.; Meyer, G.; John, U. \& Kocher, T. Epidemiological evaluation of the multifactorial aetiology of abfractions. J. Oral Rehabil., 33(1):17-25, 2006.

Borcic, J.; Anic, I.; Urek, M. M. \& Ferreri, S. The prevalence of noncarious cervical lesions in permanent dentition. J. Oral Rehabil., 31(2):117-23, 2004.
Brackett, W. W.; Brackett, M. G.; Dib, A.; Franco, G. \& Estudillo, H. Eighteen-month clinical performance of a self-etching primer in unprepared class V resin restorations. Oper. Dent., 30(4):424-9, 2005.

Braga, R. R.; Meira, J. B.; Boaro, L. C. \& Xavier, T. A. Adhesion to tooth structure: a critical review of "macro" test methods. Dent. Mater., 26(2):e38-49, 2010. 
Cardoso, M. V.; de Almeida Neves, A.; Mine, A.; Coutinho, E.; Van Landuyt, K.; De Munck, J. \& Van Meerbeek, B. Current aspects on bonding effectiveness and stability in adhesive dentistry. Aust. Dent. J., 56(Suppl. 1):31-44, 2011.

Drummond, J. L. Degradation, fatigue, and failure of resin dental composite materials. J. Dent. Res., 87(8):710-9, 2008.

Ghassemieh, E. Evaluation of sources of uncertainties in microtensile bond strength of dental adhesive system for different specimen geometries. Dent. Mater., 24(4):536-47, 2008.

Grippo, J. O.; Simring, M. \& Schreiner, S. Attrition, abrasion, corrosion and abfraction revisited: a new perspective on tooth surface lesions. J. Am. Dent. Assoc., 135(8):1109-18, 2004.

Guimaraes, J. C.; Guimaraes Soella, G.; Brandao Durand, L.; Horn, F.; Narciso Baratieri, L.; Monteiro, S. Jr. \& Belli, R. Stress amplifications in dental non-carious cervical lesions. J. Biomech., 47(2):410-6, 2014

Heintze, S. D. Clinical relevance of tests on bond strength, microleakage and marginal adaptation. Dent. Mater., 29(1):59-84, 2013.

Ivancik, J. \& Arola, D. D. The importance of microstructural variations on the fracture toughness of human dentin. Biomaterials, 34(4):86474, 2013.

Karan, K.; Yao, X.; Xu, C. \& Wang, Y. Chemical profile of the dentin substrate in non-carious cervical lesions. Dent. Mater., 25(10):120512,2009 .

Korkmaz, Y.; Gurgan, S.; Firat, E. \& Nathanson, D. Shear bond strength of three different nano-restorative materials to dentin. Oper. Dent., $35(1): 50-7,2010$

Kwong, S. M.; Cheung, G. S.; Kei, L. H.; Itthagarun, A.; Smales, R. J.; Tay, F. R. \& Pashley, D. H. Micro-tensile bond strengths to sclerotic dentin using a self-etching and a total-etching technique. Dent. Mater., 18(5):359-69, 2002.

Luque-Martinez, I. V.; Mena-Serrano, A.; Muñoz, M. A.; Hass, V.; Reis, A. \& Loguercio, A. D. Effect of bur roughness on bond to sclerotic dentin with self-etch adhesive systems. Oper. Dent., 38(1):39-47, 2013.

Martín, N.; García, A.; Vera, V.; Garrido, M. A. \& Rodríguez, J. Mechanical characterization of sclerotic occlusal dentin by nanoindentation and nanoscratch. Am. J. Dent., 23(2):108-12, 2010.

Ozer, F. \& Blatz, M. B. Self-etch and etch-and-rinse adhesive systems in clinical dentistry. Compend. Contin. Educ. Dent., 34(1):12-4, 2013.

Pashley, D. H.; Tay, F. R.; Yiu, C.; Hashimoto, M.; Breschi, L.; Carvalho, R. M. \& Ito, S. Collagen degradation by host-derived enzymes during aging. J. Dent. Res., 83(3):216-21, 2004.

Peumans, M.; De Munck, J.; Van Landuyt, K. L.; Poitevin, A.; Lambrechts, P. \& Van Meerbeek, B. A 13-year clinical evaluation of two three-step etch-and-rinse adhesives in non-carious class-V lesions. Clin. Oral Investig., 16(1):129-37, 2012.
Placido, E.; Meira, J. B.; Lima, R. G.; Muench, A.; de Souza, R. M. \& Ballester, R. Y. Shear versus micro-shear bond strength test: a finite element stress analysis. Dent. Mater., 23(9):1086-92, 2007.

Ritter, A. V.; Heymann, H. O.; Swift, E. J. Jr.; Sturdevant, J. R. \& Wilder, A. D. Jr. Clinical evaluation of an all-in-one adhesive in non-carious cervical lesions with different degrees of dentin sclerosis. Oper. Dent., 33(4):370-8, 2008.

Scherle, W. A simple method for volumetry of organs in quantitative stereology. Mikroskopie, 26(1):57-60, 1970.

Scherrer, S. S.; Cesar, P. F. \& Swain, M.V. Direct comparison of the bond strength results of the different test methods: a critical literature review. Dent. Mater., 26(2):e78-93, 2010.

Spencer, P.; Wang, Y.; Katz, J. L. \& Misra, A. Physicochemical interactions at the dentin/adhesive interface using FTIR chemical imaging. J. Biomed. Opt., 10(3):031104, 2005.

Tjaderhane, L.; Nascimento, F. D.; Breschi, L.; Mazzoni, A.; Tersariol, I. L.; Geraldeli, S.; Tezvergil-Mutluay, A.; Carrilho, M. R.; Carvalho, R. M.; Tay, F. R. \& Pashley, D. H. Optimizing dentin bond durability: control of collagen degradation by matrix metalloproteinases and cysteine cathepsins. Dent. Mater. 29(1):116-35, 2013.

Tschanz, S. A.; Burri, P. H \& Weibel, E. R. A simple tool for stereological assessment of digital images: the STEPanizer. J. Microsc., 243(1):47-59, 2011.

van Dijken, J. W.; Sunnegardh-Grönberg, K. \& Lindberg, A. Clinical long-term retention of etch-and-rinse and self-etch adhesive systems in non-carious cervical lesions. A 13 years evaluation. Dent. Mater., 23(9):1101-7, 2007.

Van Meerbeek, B.; Van Landuyt, K.; De Munck, J.; Hashimoto, M.; Peumans, M.; Lambrechts, P.; Yoshida, Y.; Inoue, S. \& Suzuki, K. Technique-sensitivity of contemporary adhesives. Dent. Mater. J., 24(1):1-13, 2005

Zakir, M.; Al Kheraif, A. A.; Asif, M.; Wong, F. S. \& Rehman, I. U. A comparison of the mechanical properties of a modified silorane based dental composite with those of commercially available composite material. Dent. Mater., 29(4):e53-9, 2013.

\section{Correspondence to:}

Gisaku Kuramochi Duhalde

Department of Restorative Dentistry

School of Dentistry

Universidad Finis Terrae

Av. Pedro de Valdivia 1509

Santiago

CHILE

Email: gkuramochi@gmail.com
Received: 11-01-2015 Accepted: 22-04-2016 